\title{
Chronic Administration of the Triazolobenzodiazepine Alprazolam Produces Opposite Effects on Corticotropin-Releasing Factor and Urocortin Neuronal Systems
}

\author{
Kelly H. Skelton, Charles B. Nemeroff, David L. Knight, and Michael J. Owens \\ Laboratory of Neuropsychopharmacology, Department of Psychiatry and Behavioral Sciences, Emory University School \\ of Medicine, Atlanta, Georgia 30322
}

In view of the substantial preclinical evidence that supports a seminal role of central corticotropin-releasing factor (CRF) neuronal systems in the physiology and pathophysiology of stress and anxiety, it is reasonable to suggest that the anxiolytic properties of benzodiazepines are mediated, at least in part, via regulation of CRFergic function. To begin to test this complex hypothesis, we examined the effects of acute and chronic administration of the triazolobenzodiazepine agonist alprazolam on CRF peptide concentrations, receptor-binding density, and mRNA expression in the CNS. Additionally, we measured mRNA expression for urocortin, a recently discovered neuropeptide that is generally considered to be a second endogenous ligand for CRF receptors. Both acute and chronic alprazolam administration was found to decrease CRF concentrations within the locus coeruleus. Furthermore, chronic alprazolam decreased basal activity of the hypothalamic-pituitary-adrenal axis, CRF mRNA expression in the central nucleus of the amygdala, and $\mathrm{CRF}_{1}$ mRNA expression and receptor binding in the basolateral amygdala. In marked contrast, urocortin mRNA expression in the Edinger-Westphal nucleus and $\mathrm{CRF}_{2 \mathrm{~A}}$ receptor binding in the lateral septum and ventromedial hypothalamus were increased. Similar findings of an inverse relationship between the $\mathrm{CRF}_{1}$ and $\mathrm{CRF}_{2 \mathrm{~A}}$ receptor systems have been reported in an anxiety model based on adverse early-life experience, suggesting the intriguing possibility that CRF neuronal systems may be comprised of two separate, but interrelated, subdivisions that can be coordinately and inversely regulated by stress, anxiety, or anxiolytic drugs.

Key words: amygdala; anxiety; benzodiazepines; corticotropin-releasing factor; locus coeruleus; stress; urocortin
The neuropeptide corticotropin-releasing factor (CRF) coordinates the endocrine response to stress via its action as the major physiological regulator of the hypothalamic-pituitary-adrenal (HPA) axis (Owens and Nemeroff, 1991). In addition to the paraventricular nucleus of the hypothalamus (PVN), CRFcontaining neurons have also been localized to extrahypothalamic limbic structures and brainstem nuclei that subserve behavioral and autonomic regulatory functions, such as the bed nucleus of the stria terminalis (BNST), the central nucleus of the amygdala (CeA), and the locus coeruleus (LC) (Swanson et al., 1983). There is overwhelming evidence (Valentino et al., 1993; Gray and Bingaman, 1996; Lee and Davis, 1997) that suggests that CRF functions as a neurotransmitter in these regions. In this manner, it is hypothesized that CRF neuronal systems are strategically located to integrate not only the endocrine but also the behavioral, immune, and autonomic responses to stress (Dunn and Berridge, 1990; Owens and Nemeroff, 1991).

Recently, the existence of two distinct CRF receptor subtypes with contrasting neuroanatomical distributions has been demonstrated: $\mathrm{CRF}_{1}$ and $\mathrm{CRF}_{2}$ (Chalmers et al., 1996). In rats, $\mathrm{CRF}_{1}$ is the predominant receptor within the pituitary, cerebellum, and neocortex. However, in nonhuman primates, there is considerable

Received July 12, 1999; revised Nov. 9, 1999; accepted Nov. 11, 1999.

This work was supported by National Institutes of Health Grants DA08705 and MH42088, as well as the National Institutes of Health Medical Scientist Training Program Grant 5 T32 GM08169.

Correspondence should be addressed to Dr. Michael J. Owens, Department of Psychiatry and Behavioral Sciences, Emory University School of Medicine, 1639 Pierce Drive, Suite 4000, Atlanta, GA 30322. E-mail: mowens@emory.edu.

Copyright (C) 2000 Society for Neuroscience $0270-6474 / 00 / 201240-09 \$ 15.00 / 0$
$\mathrm{CRF}_{2}$ receptor expression and binding in the neocortex and anterior pituitary (Sanchez et al., 1999). The $\mathrm{CRF}_{2}$ receptor consists of at least two splice variants, $\mathrm{CRF}_{2 \mathrm{~A}}$ and $\mathrm{CRF}_{2 \mathrm{~B}}$. The former is more prevalent in subcortical regions, particularly the lateral septum (LS), ventromedial hypothalamus (VMH), and dorsal raphe, whereas the latter is more abundant in the periphery.

Another relatively recent and important discovery is that of urocortin, a second endogenous mammalian ligand for the CRF receptors (Vaughan et al., 1995; Donaldson et al., 1996; Z hao et al., 1998). Urocortin binds with equal affinity to both CRF receptor subtypes but demonstrates $\sim 10$-fold higher affinity for $\mathrm{CRF}_{2}$ receptors than does CRF itself (Chalmers et al., 1996). In the rat, urocortin-containing perikarya and urocortin mRNA expression are most prominent in the Edinger-Westphal nucleus (EWN) and the lateral superior olive (Vaughan et al., 1995), regions that do not contain CRF mRNA. The highest density of urocortin innervation is observed in the LS and dorsal raphe (Vaughan et al., 1995; Wong et al., 1996; Kozicz et al., 1998). It is of interest to note that these two regions nearly exclusively express $\mathrm{CRF}_{2 \mathrm{~A}}$ mRNA. This overlapping distribution, along with the higher affinity of urocortin for the $\mathrm{CRF}_{2}$ receptor as compared with $\mathrm{CRF}$, provide evidence that urocortin may be the endogenous $\mathrm{CRF}_{2}$ ligand.

Although little is known about the role of urocortin and the $\mathrm{CRF}_{2}$ receptor system in stress and the pathophysiology of psychiatric disorders, there is considerable data supporting a role for CRF in the pathogenesis of anxiety disorders. Central administration of CRF produces behavioral evidence of anxiety in laboratory animals (Dunn and Berridge, 1990), and transgenic mice 
that overexpress CRF also demonstrate heightened anxiety (Heinrichs et al., 1997a). In humans, elevated levels of CRF have been found in the CSF of post-traumatic stress disorder patients (Bremner et al., 1997; Baker et al., 1999) and during alcohol withdrawal, both of which are characterized by increased anxiety symptom severity (Hawley et al., 1994; Adinoff et al., 1996). Conversely, CRF antagonists and antisense oligonucleotides directed against either CRF or $\mathrm{CRF}_{1}$ receptor mRNA are effective anxiolytics in laboratory animal studies (Heinrichs et al., 1992; Rassnick et al., 1993; Skutella et al., 1994; Liebsch et al., 1995). The recent demonstration that $\mathrm{CRF}_{1}$ receptor knock-out mice exhibit decreased basal and stress-induced anxiety further supports a role for CRF in the mediation of anxiogenic behaviors (Timpl et al., 1998).

Benzodiazepines, a class of drugs that potentiate GABAmediated $\mathrm{Cl}^{-}$current and have been clinically used as anxiolytics since the 1960s, appear to produce many effects opposite to those of centrally administered CRF. These drugs have been demonstrated to suppress HPA axis activation (Krulik and Cerny, 1971; Kalogeras et al., 1990; Rorher et al., 1994; Cowley et al., 1995), to attenuate stress-induced CRF neuronal activation ( $c$-fos mRNA), as well as the subsequent increase in CRF production (CRF mRNA) and release (Imaki et al., 1995; Pich et al., 1995), and to block or diminish the anxiogenic effects of CRF as measured behaviorally (Britton et al., 1985; Swerdlow et al., 1986; Dunn and File, 1987).

In view of the substantial evidence relating CRF to stress and anxiety, it seems plausible that the anxiolytic actions of benzodiazepines may be at least partially attributable to their demonstrated ability to antagonize the production, release, and behavioral effects of CRF. To test this hypothesis, we sought to examine whether acute or chronic administration of the benzodiazepine alprazolam altered measurable parameters of central CRF and/or urocortin activity, including peptide and receptor concentrations or binding and mRNA expression.

\section{MATERIALS AND METHODS}

\section{Animals}

Male Sprague Dawley rats (225-275 gm on arrival; Charles River Laboratories, Raleigh, NC) were housed three per cage (acute-dosing experiment) with food and water available ad libitum in an environmentally controlled animal facility with a $12 \mathrm{hr}$ light/dark cycle (lights on at 0730 $\mathrm{hr}$ ). Rats receiving alprazolam incorporated into a liquid diet for the chronic-dosing experiments were housed individually and without access to a separate food supply. Animals were weighed and handled daily starting $7 \mathrm{~d}$ before the experiment (acute-dosing experiment) or throughout the course of the experiment (chronic-dosing experiment). Rats were killed by decapitation between 0900 and 1030 hr. After decapitation, brains were rapidly removed, frozen on dry ice, and stored at $-80^{\circ} \mathrm{C}$ until cryostat sectioning or dissection.

\section{Drug treatment}

Acute-dosing experiment. Rats $(n=12$ per group) received a single subcutaneous injection of either (1) alprazolam $[0.00 \mathrm{mg} / \mathrm{kg}$ (vehicle) or $0.10,0.33,1.0$, or $3.3 \mathrm{mg} / \mathrm{kg}$ in $50 \%$ polyethylene glycol (PEG) 400 (Sigma, St. Louis, MO) in water], (2) flumazenil [0.00 $\mathrm{mg} / \mathrm{kg}$ (vehicle) or $0.33,1.0,3.3$, or $10.0 \mathrm{mg} / \mathrm{kg}$ in $50 \%$ PEG 400], or (3) FG7142 [0.00 mg/kg (vehicle) or $0.33,1.0,3.3$, or $10.0 \mathrm{mg} / \mathrm{kg}$ in $45 \%$ hydroxypropyl $\beta$ cyclodextrin (Research Biochemicals, Natick, MA)]. The injection volume was $1 \mathrm{ml} / \mathrm{kg}$, and injections were made in staggered order, between 0730 and $0900 \mathrm{hr}$. Rats were killed exactly $90 \mathrm{~min}$ after drug or vehicle injection.

Chronic-dosing experiment. Based on our previous studies (Owens et al., 1991), an oral alprazolam dose of $90 \mathrm{mg} \cdot \mathrm{kg}^{-1} \cdot \mathrm{d}^{-1}$ was administered, with the alprazolam content of the diet adjusted daily for the rats' weight. Rats ( $n=16$ per group) received a liquid, fat emulsion-based diet (Bio-Serv, Frenchtown, NJ) supplemented with $0.01 \%$ (w/v) saccharin and varying amounts of alprazolam dissolved in PEG 400 or PEG 400 vehicle alone (control diet). The diet was available ad libitum and was the only source of food available to the rats. Intake was recorded daily for individual rats throughout the course of the experiment. The rats were killed after $14 \mathrm{~d}$ of feeding.

\section{RIAs}

ACTH RIA. Trunk blood was collected on ice in EDTA-containing glass tubes and centrifuged for $10 \mathrm{~min}$ at $2500 \mathrm{rpm}$. ACTH was measured in duplicate samples of rat plasma by a two-site immunoradiometric assay (Nichols Diagnostics, San Juan Capistrano, CA) with a coefficient of variation of $5 \%$ and sensitivity (blank $\pm 2 \mathrm{SD}$ ) of $1 \mathrm{pg} / \mathrm{ml}$.

Corticosterone RIA. Trunk blood was collected on ice in polycarbonate tubes and centrifuged for $10 \mathrm{~min}$ at $2500 \mathrm{rpm}$. Corticosterone was assayed in duplicate samples of rat serum by double antibody RIA (ICN Biochemicals, Costa Mesa, CA) with a coefficient of variation of $6 \%$ and sensitivity (blank $\pm 2 \mathrm{SD}$ ) of $1.2 \mathrm{ng} / \mathrm{ml}$.

CRF RIA. Regional brain tissue samples from the acute alprazolam experiment, as well as the amygdala samples from the chronic alprazolam experiment, were dissected as described in Owens et al. (1989). Briefly, the frozen brains were sliced with a razor blade into sections of varying thickness $(\sim 1 \mathrm{~mm}$ for the $\mathrm{LC}$ and $2-3 \mathrm{~mm}$ for the amygdala) that were then dissected on ice with a scalpel to remove the region of interest, based on the atlas of Paxinos and Watson (1986). Because of concerns about the proximity of the LC to the parabrachial nucleus, the LC samples from the chronic alprazolam experiment were micropunched $(0.8 \mathrm{~mm})$ from $300-\mu \mathrm{m}$-thick coronal frozen brain slices thaw-mounted onto glass slides. The CRF concentrations in these brain tissue samples were determined using a modified version of the RIA originally described by Vale, as modified by Ladd et al. (1996). The primary antibody was either oC30 rabbit anti-CRF (acute experiments; donated by W. Vale, The Salk Institute for Biological Studies, La Jolla, CA) or Peninsula (Belmont, CA) rabbit anti-CRF (chronic experiments) at a final dilution of $1: 16,000$ or $1: 70,000$, respectively. A standard curve was prepared with rat, human CRF (Bachem, Torrance, CA) comprising the concentration range from 0.625 to $5120 \mathrm{pg}$ /tube. The sensitivity of the assay was $1.25 \mathrm{pg} / \mathrm{tube}$.

\section{In situ hybridization}

Serial coronal brain sections $(20 \mu \mathrm{m})$ were prepared on a cryostat at $-18^{\circ} \mathrm{C}$, thaw-mounted onto SuperFrost Plus slides (Fisher, Pittsburgh, PA) under RNase-free conditions, and stored with Humi-Cap desiccant capsules (Life Technologies, Gaithersburg, MD) at $-80^{\circ} \mathrm{C}$ until the assay. In situ hybridization was performed according to the procedures described by Simmons et al. (1989) with minor modifications. Briefly, slides were warmed in a stepwise manner to room temperature, post-

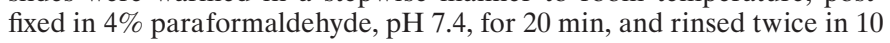
$\mathrm{mmol} / \mathrm{l} \mathrm{PBS}, \mathrm{pH} 7.4$, for $2 \mathrm{~min}$. Next, the slides were treated for $15 \mathrm{~min}$ with proteinase K (Promega, Madison, W I; $10 \mu \mathrm{g} / \mathrm{ml}$ in $0.1 \mathrm{~mol} / 1$ Tris with $50 \mathrm{mmol} / 1 \mathrm{EDTA}$ ) at room temperature, followed by $10 \mathrm{~min}$ of acetylation ( $0.5 \%$ acetic anhydride in $0.1 \mathrm{~mol} / 1$ triethanolamine, $\mathrm{pH} 8.0)$, two rinses in $2 \times$ SSC, and dehydration through a graded ethanol series. The sections were then air-dried for at least $1 \mathrm{hr}$ before hybridization.

The CRF riboprobe was constructed from a $1.2 \mathrm{~kb}$ EcoRI fragment of a full-length rat CRF cDNA (K. Mayo, Northwestern University, Evanston, IL) subcloned into a pBluescript II-SK ${ }^{+}$plasmid. The urocortin riboprobe was constructed from an $\sim 0.6 \mathrm{~kb} E c o$ RI-EcoRI fragment ligated into a pBluescript II-SK ${ }^{+}$plasmid (W. Vale, The Salk Institute for Biological Studies). The insert includes $\sim 70 \mathrm{bp}$ of $5^{\prime}$-untranslated cDNA and the full-length coding region for rat urocortin, followed by $\sim 130$ bp of $3^{\prime}$-untranslated cDNA. The $\mathrm{CRF}_{1}$ riboprobe was constructed from a $1.3 \mathrm{~kb}$ Pst $\mathrm{I}-P s t \mathrm{I}$ fragment, containing the full-length coding region for the rat $\mathrm{CRF}_{1}$ receptor, ligated into a pBluescript II-SK ${ }^{+}$plasmid (W. Vale, The Salk Institute for Biological Studies). The $\mathrm{CRF}_{2 \mathrm{~A}}$ riboprobe was constructed from a $275 \mathrm{bp}$ fragment, encoding the $\mathrm{N}$-terminal region of the $\mathrm{CRF}_{2 \mathrm{~A}}$ receptor, ligated into a pBluescript II-SK ${ }^{+}$plasmid (T. Lovenberg, Neurocrine Biosciences, San Diego, CA). Radiolabeled antisense cRNAs were synthesized by incorporating either $\alpha-{ }^{35} \mathrm{~S}-\mathrm{UTP}$ (DuPont NEN, Boston, MA) into the CRF and urocortin probes or $\alpha^{-35} \mathrm{~S}-\mathrm{CTP}$ plus $\alpha-{ }^{35} \mathrm{~S}-\mathrm{UTP}$ into the $\mathrm{CRF}_{1}$ and $\mathrm{CRF}_{2 \mathrm{~A}}$ receptor probes. The transcription reactions were performed using the Ambion MAXIscript kit (Austin, TX) with SP6 (CRF), T7 (urocortin and $\mathrm{CRF}_{1}$ ), or T3 $\left(\mathrm{CRF}_{2 \mathrm{~A}}\right) \mathrm{RNA}$ polymerases according to the instructions provided. After transcription and removal of the cDNA template with $2 \mathrm{U}$ of DNase (Ambion), the cRNA probes were recovered via ethanol precipitation 
and/or gel filtration using a G-50 Sephadex Quick Spin column (Boehringer Mannheim, Indianapolis, IN).

The brain sections were hybridized overnight at $58-60^{\circ} \mathrm{C}$ with $2 \times 10^{6}$ $\mathrm{cpm}$ of ${ }^{35} \mathrm{~S}$-labeled cRNA probe diluted into hybridization buffer $(50 \%$ formamide, $10 \%$ dextran sulfate, $0.3 \mathrm{~mol} / 1 \mathrm{NaCl}, 1 \times$ Denhardt's solution, $10 \mathrm{mmol} / 1 \mathrm{Tris}, 1 \mathrm{mmol} / 1 \mathrm{EDTA}, 2 \mathrm{mg} / \mathrm{ml}$ yeast tRNA, and 10 $\mathrm{mmol} / \mathrm{l} \mathrm{DTT}$ ) in humidified Nunc trays (Nunc, Naperville, IL). The next day, slides were allowed to cool to room temperature before being washed four times in $4 \times \mathrm{SSC}$ for $5 \mathrm{~min}$ on a rotating platform at $60 \mathrm{rpm}$. The sections were then treated with $250 \mu \mathrm{g} / \mathrm{ml}$ RNase A (Promega) for $30 \mathrm{~min}$ at $37^{\circ} \mathrm{C}$. Subsequently, the slides underwent a series of SSC washes (supplemented with $1 \mathrm{mmol} / \mathrm{l}$ DTT) with salt concentrations decreasing from $2 \times$ to $0.5 \times$, followed by a $60 \mathrm{~min}$ high-stringency wash with $0.1 \times \mathrm{SSC}+1 \mathrm{mmol} / 1 \mathrm{DTT}$ at $60^{\circ} \mathrm{C}$ and then dehydration through a graded ethanol series. The slides were air-dried for at least $1 \mathrm{hr}$ and then apposed to Kodak Biomax MR film (Eastman Kodak, Rochester, $\mathrm{NY}$ ) for $12 \mathrm{hr}$ to $21 \mathrm{~d}$ (depending on the probe and brain region examined) with ${ }^{14} \mathrm{C}$ standards (Amersham, Piscataway, NJ). Controls performed to establish specificity of the signal included hybridization with sense-strand probes, as well as predigestion with RNase A.

\section{$C R F$ receptor autoradiography}

After a modification of the techniques of De Souza et al. (1985) and Primus et al. (1997), ex vivo CRF receptor autoradiography was performed on $15 \mu \mathrm{m}$ rat brain sections mounted on SuperFrost Plus slides (Fisher) and stored as described above until assay. Brain sections were fixed for $2 \mathrm{~min}$ in $0.1 \%$ paraformaldehyde followed by a $15 \mathrm{~min}$ incubation in assay buffer $\left(50 \mathrm{mmol} / 1\right.$ Tris, $10 \mathrm{mmol} / 1 \mathrm{MgCl}_{2}, 2 \mathrm{mmol} / 1$ EGTA, $0.1 \% \mathrm{BSA}, 0.1 \mathrm{mmol} / 1$ bacitracin, and $0.1 \%$ aprotinin, $\mathrm{pH} 7.5$ ) to remove endogenous CRF. Next, triplicate slides containing adjacent brain sections were incubated for $2 \mathrm{hr}$ at room temperature in one of three conditions: (1) $0.1 \mathrm{nmol} / 1$ radiolabeled ${ }^{125}$ I-sauvagine (DuPont NEN) to determine total binding at both the $\mathrm{CRF}_{1}$ and $\mathrm{CRF}_{2}$ receptor subtypes, (2) $0.1 \mathrm{nmol} / 1$ radiolabeled ${ }^{125} \mathrm{I}$-sauvagine $+1 \mu \mathrm{mol} / 1 \mathrm{CP}-154,526$ $\left(\mathrm{CRF}_{1}\right.$-specific antagonist) to determine $\mathrm{CRF}_{2}$ receptor-specific binding, or (3) $0.1 \mathrm{nmol} / 1$ radiolabeled ${ }^{125}$ I-sauvagine $+1 \mu \mathrm{mol} / 1$ unlabeled sauvagine (American Peptide Company, Sunnyvale, CA) to determine nonspecific binding. After the incubation, unbound radioligand was removed by two $5 \mathrm{~min}$ rinses in ice-cold $\left(4^{\circ} \mathrm{C}\right) \mathrm{PBS}+1 \% \mathrm{BSA}$ on a rotating platform at $60 \mathrm{rpm}$, followed by two brief dips in ice-cold distilled, deionized $\mathrm{H}_{2} \mathrm{O}$. Slides were then rapidly dried with a blow dryer on the coldest setting and apposed to Kodak Biomax MR film (Eastman Kodak) with ${ }^{125} \mathrm{I}$-microscale standards (Amersham) for $80-90 \mathrm{hr}$.

\section{Image analysis}

Images from the in situ hybridization and receptor autoradiography films were digitized with a Dage-MTI CCD-72 (Michigan City, IN) image analysis system equipped with a Nikon camera. Semiquantitative analysis was performed using Scion Image (version 3.0b) software. Optical densities were calibrated against ${ }^{14} \mathrm{C}$-standards (in situ hybridization films) or ${ }^{125} \mathrm{I}$-microscale standards (receptor autoradiography films) and expressed in terms of $\mathrm{nCi} / \mathrm{gm}$ of tissue equivalent. For the purpose of quantifying mRNA levels, specific signal density was determined relative to neutral background density present in the same brain section. For the purpose of quantifying $\mathrm{CRF}$ receptor levels, $\mathrm{CRF}_{1}$ receptor-specific binding was calculated as "total binding $-\mathrm{CRF}_{2 \mathrm{~A}}$ receptor binding," and $\mathrm{CRF}_{2 \mathrm{~A}}$ receptor-specific binding was calculated as " $\mathrm{CRF}_{2 \mathrm{~A}}$ receptor binding - nonspecific binding." In all cases, two to four sections per region were matched for rostrocaudal level according to the atlas of Paxinos and Watson (1986) and used to produce a single value for each animal.

\section{Drugs}

Alprazolam was a gift from Upjohn (Kalamazoo, MI). Flumazenil was a gift from Hoffmann-LaRoche (Basel, Switzerland). FG7142 was purchased from Research Biochemicals. CP-154,526 was synthesized and provided by Dr. Mark M. Goodman (Emory University, Atlanta, GA).

\section{Statistics}

Significant differences were evaluated by one- or two-tailed $t$ tests or one-way ANOVA as appropriate. Exact details of data analysis are provided in the corresponding figure legends. All data are expressed as the mean \pm SEM.

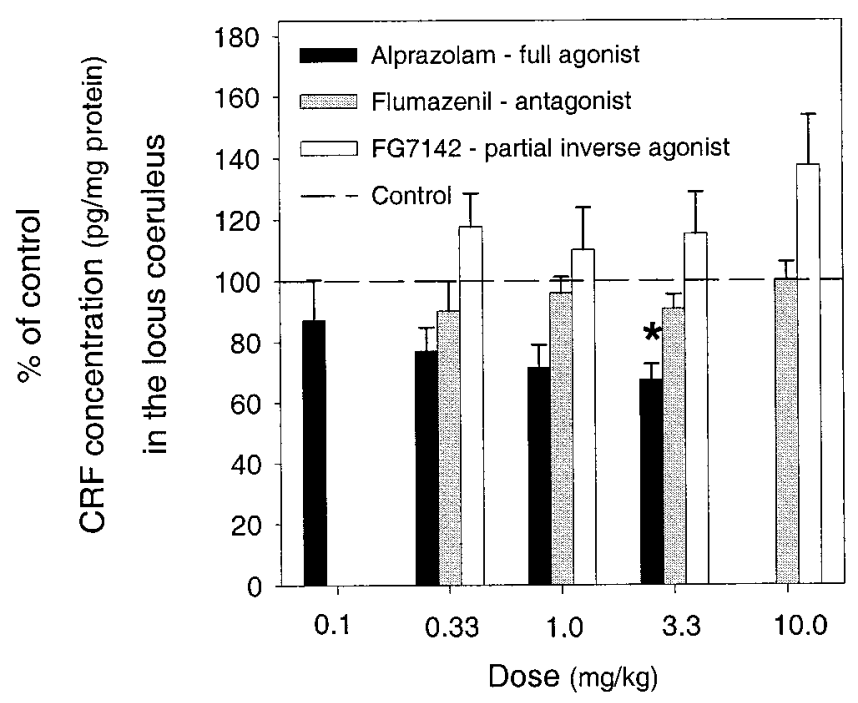

Figure 1. CRF concentrations in the LC after acute administration of compounds active at the benzodiazepine receptor. All drugs were administered subcutaneously, $90 \mathrm{~min}$ before death. CRF concentrations were determined via radioimmunoassay in LC homogenates. Each vertical bar represents the mean $\pm \operatorname{SEM}\left(n=12\right.$ rats per group). ${ }^{*} p<0.05$ after one-tailed statistical analysis of the ANOVA, based on the presumption of an alprazolam-induced decrease in LC CRF.

\section{RESULTS \\ CRF concentrations after acute benzodiazepine administration}

We have observed previously that acute administration of the benzodiazepine full agonist alprazolam $(1 \mathrm{mg} / \mathrm{kg})$ decreases CRF concentrations in the LC. To characterize this action further, dose-response curves after acute administration were generated for three drugs spanning the spectrum of intrinsic efficacy for the benzodiazepine receptor (agonist, antagonist, and partial inverse agonist). The brains of male Sprague Dawley rats were dissected into 14 regions after acute administration of drugs active at the benzodiazepine receptor: median eminence, prefrontal cortex, frontal/parietal cortex, cingulate cortex, BNST, septum, amygdala, piriform cortex, hypothalamus, hippocampus, entorhinal cortex, dorsal raphe, cerebellum, and LC. Only in the LC were CRF concentrations altered in a manner consistent with the pharmacological action of the drug at the benzodiazepine receptor. Alprazolam, a full agonist, dose-dependently decreased CRF concentrations in the LC by up to $32 \%[p<0.05$ via one-way ANOVA with one-tailed analysis based on the results of our previous data (Owens et al., 1989, 1991) yielding the hypothesis that CRF concentrations would decrease in the LC after alprazolam treatment; Fig. 1]. Conversely, FG7142, a partial inverse agonist, caused a trend to dose-dependently increase CRF concentrations in this region by up to $37 \%$. The benzodiazepine antagonist flumazenil did not acutely alter CRF concentrations in the LC at any dose tested.

\section{CRF concentrations and pituitary-adrenal axis activity after chronic benzodiazepine administration}

Figure 2 illustrates the diminished basal activity of the HPA axis after 2 weeks of treatment with alprazolam. Plasma ACTH concentrations were decreased by $51 \%(8.6 \pm 1.7$ vs $17.7 \pm 5.1$ $\mathrm{pg} / \mathrm{ml})$, and serum corticosterone concentrations were decreased by $77 \%(2.5 \pm 0.4$ vs $10.7 \pm 3.8 \mathrm{ng} / \mathrm{ml} ; p<0.05)$ in the alprazolam-treated rats compared with the control rats. It is also 


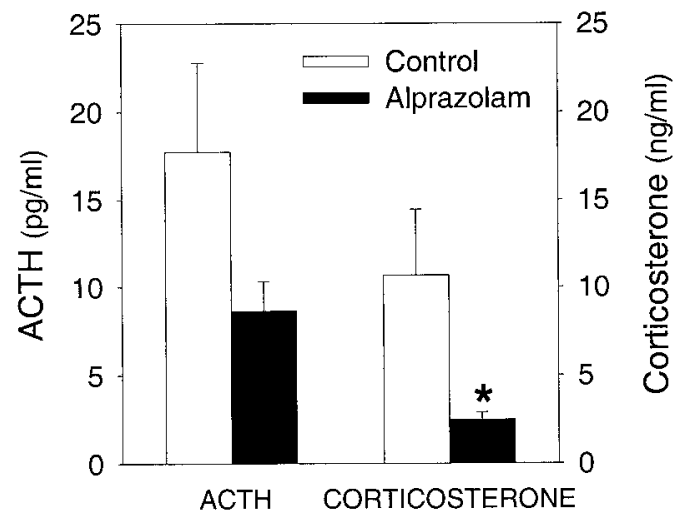

Figure 2. Chronic alprazolam decreases serum corticosterone, suggesting decreased basal activity of the HPA axis. Plasma ACTH and serum corticosterone were measured via radioimmunoassay after $14 \mathrm{~d}$ of incorporation of alprazolam into the diet of male Sprague Dawley rats at a concentration of $90 \mathrm{mg} \cdot \mathrm{kg}^{-1} \cdot \mathrm{d}^{-1}$. Each vertical bar represents the mean \pm SEM ( $n=16$ per group). ${ }^{*} p<0.05$ versus controls after analysis by a two-tailed $t$ test.

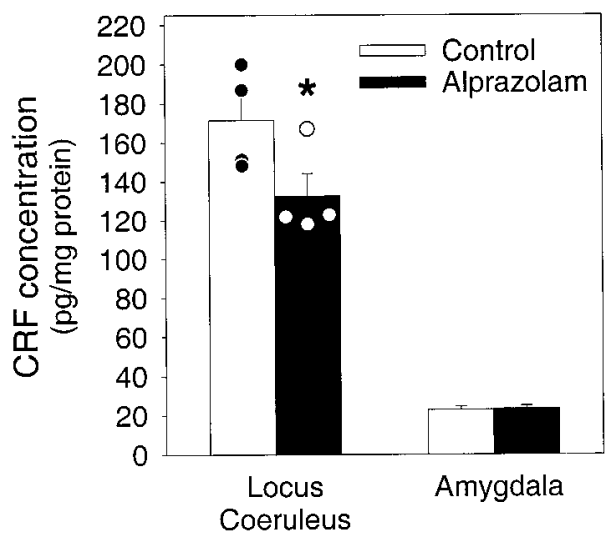

Figure 3. Chronic alprazolam decreases CRF concentrations in the locus coeruleus. After $14 \mathrm{~d}$ of incorporation of alprazolam into the diet of male Sprague Dawley rats at a concentration of $90 \mathrm{mg} \cdot \mathrm{kg}^{-1} \cdot \mathrm{d}^{-1}$, CRF concentrations were measured via radioimmunoassay in locus coeruleus micropunch samples $(n=4$ per group) and amygdala homogenates $(n=8$ per group). Each vertical bar represents the mean \pm SEM; circles represent individual values of CRF concentration in the locus coeruleus. ${ }^{*} p<$ 0.05 versus controls after analysis by a one-tailed $t$ test, based on the presumption of an alprazolam-induced decrease in LC CRF.

important to note that the low ACTH and corticosterone levels in the controls demonstrate that these rats were nonstressed at the time of death. Therefore, the changes in CRF neuronal activity reported in the alprazolam-treated rats are thought to represent alterations in baseline activity rather than an attenuation of stress-induced responses.

Similar to the findings in the acute studies, CRF concentrations were decreased in the LC by $\sim 25 \%$ after chronic alprazolam treatment (Fig. 3, $132.5 \pm 11.6$ vs $171.6 \pm 12.9 \mathrm{pg}$ of $\mathrm{CRF} / \mathrm{mg}$ of protein; $p<0.05$ after analysis by a one-tailed $t$ test based on the hypothesis described above). No changes in CRF concentrations were demonstrated in the amygdala.

\section{CRF mRNA expression}

CRF mRNA expression was examined in the BNST, PVN, CeA, and Barrington's nucleus. These regions have been implicated in CRF-induced anxiogenic behavior (Krahn et al., 1988; Heinrichs et al., 1992; Lee and Davis, 1997) and/or exhibit altered CRF

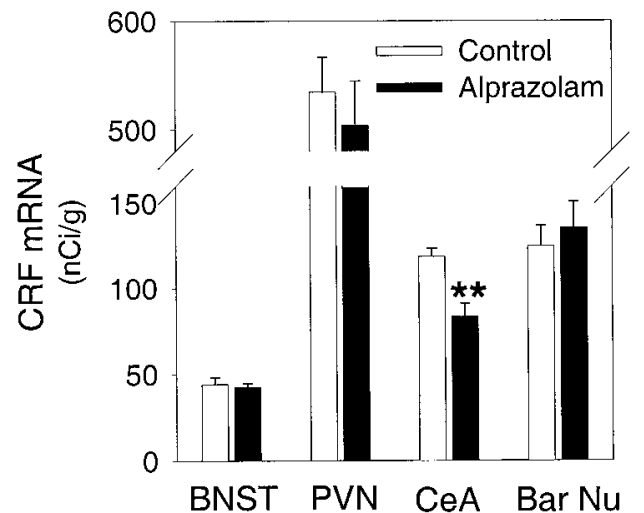

Figure 4. Chronic alprazolam decreases CRF mRNA expression in the $\mathrm{CeA}$. After $14 \mathrm{~d}$ of incorporation of alprazolam into the diet of male Sprague Dawley rats at a dose of $90 \mathrm{mg} \cdot \mathrm{kg}^{-1} \cdot \mathrm{d}^{-1}$, CRF mRNA expression was measured via densitometric analysis subsequent to in situ hybridization performed in the BNST, PVN, CeA, and Barrington's nucleus (Bar $\mathrm{Nu})$. Each vertical bar represents the mean $\pm \operatorname{SEM}(n=8$ per group). Two to four slices were quantified per region per rat. ${ }^{*} p<0.01$ versus controls after analysis by a two-tailed $t$ test.

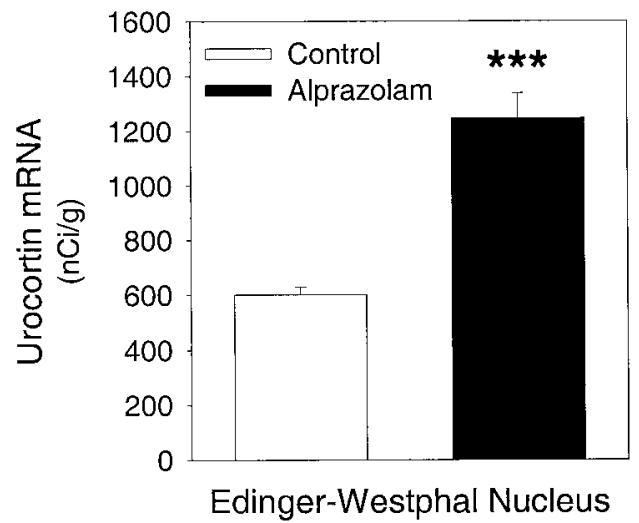

Figure 5. Chronic alprazolam increases urocortin mRNA expression in the Edinger-Westphal nucleus. After $14 \mathrm{~d}$ of incorporation of alprazolam into the diet of male Sprague Dawley rats at a dose of $90 \mathrm{mg} \cdot \mathrm{kg}^{-1} \cdot \mathrm{d}^{-1}$, urocortin mRNA expression was measured via densitometric analysis subsequent to in situ hybridization performed in the Edinger-Westphal nucleus. Each vertical bar represents the mean \pm SEM ( $n=8$ per group). Three slices were quantified per rat. ${ }^{* * *} p<0.001$ versus controls after analysis by a two-tailed $t$ test.

mRNA expression after stress (Chappell et al., 1986; Imaki et al., 1991; Kalin et al., 1994; Hatalski et al., 1998; Hsu et al., 1998). Within the CeA, CRF mRNA expression was decreased by $30 \%$ in the alprazolam-treated rats compared with the controls (Fig. 4, $83.4 \pm 8.0$ vs $118.8 \pm 4.7 \mathrm{nCi} / \mathrm{gm} ; p<0.01)$. No alterations in CRF mRNA expression were demonstrated in the other three regions examined.

\section{Urocortin mRNA expression}

Urocortin mRNA expression was examined in the EWN, the region of highest expression of this peptide within the brain, and was found to be increased by $107.3 \%$ in the rats that received chronic alprazolam treatment compared with the controls (Fig. 5, $1246.5 \pm 92.0$ vs $601.3 \pm 26.7 \mathrm{nCi} / \mathrm{gm} ; p<0.001)$.

\section{CRF receptor binding and mRNA expression}

$\mathrm{CRF}_{1}$ receptor mRNA expression was found to be slightly $(12.5 \%)$ but significantly decreased in the frontal/parietal cere- 
A

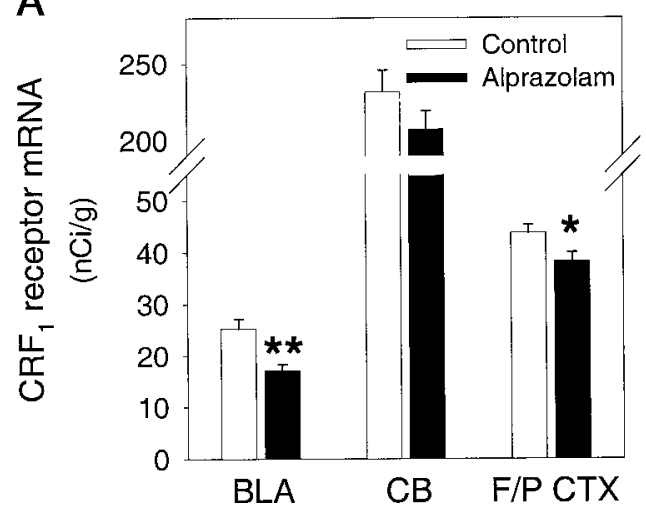

B

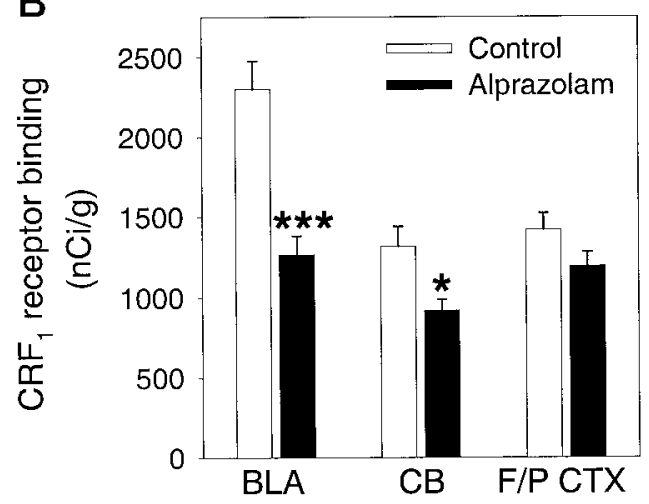

Figure 6. Alterations in $\mathrm{CRF}_{1}$ receptor function after chronic alprazolam treatment. $a$, Chronic alprazolam decreases $\mathrm{CRF}_{1}$ receptor mRNA in the basolateral amygdala $(B L A)$ and frontal/parietal cerebral cortex $(F / P$ $C T X)$. After $14 \mathrm{~d}$ of incorporation of alprazolam into the diet of male Sprague Dawley rats at a dose of $90 \mathrm{mg} \cdot \mathrm{kg}^{-1} \cdot \mathrm{d}^{-1}, \mathrm{CRF}_{1}$ receptor mRNA expression was measured via densitometric analysis subsequent to in situ hybridization in the $B L A$, cerebellum $(C B)$, and $F / P C T X$. Each vertical bar represents the mean \pm SEM $(n=8$ per group). Three to four slices were quantified per region per rat. ${ }^{*} p<0.05$ and ${ }^{*} p<0.01$ versus controls after analysis by a two-tailed $t$ test. $b$, Chronic alprazolam decreases $C \mathrm{FF}_{1}$ receptor-binding density in the $B L A$ and $C B$. After $14 \mathrm{~d}$ of incorporation of alprazolam into the diet of male Sprague Dawley rats at a dose of $90 \mathrm{mg} \cdot \mathrm{kg}^{-1} \cdot \mathrm{d}^{-1}, \mathrm{CRF}_{1}$ receptor binding was measured by densitometric analysis subsequent to receptor autoradiography performed in the $C B, B L A$, and $F / P C T X$. Total binding was determined using $0.1 \mathrm{nmol} / 1^{125} \mathrm{I}$-sauvagine. $\mathrm{CRF}_{2 \mathrm{~A}}$ binding was determined in the presence of $1 \mu \mathrm{mol} / 1 \mathrm{CP}-154,526\left(\mathrm{CRF}_{1}\right.$-selective antagonist). Nonspecific binding was determined in the presence of $1 \mu \mathrm{mol} / 1$ sauvagine. $\mathrm{CRF}_{1}$ receptor-specific binding was calculated as total binding $-\mathrm{CRF}_{2 \mathrm{~A}}$ binding. Each vertical bar represents the mean $\pm \operatorname{SEM}(n=8$ per group). Three to four slices were quantified per region per rat. ${ }^{*} p<0.05$ and ${ }^{* * *} p<0.001$ versus controls after analysis by a two-tailed $t$ test.

bral cortex of the alprazolam-treated rats compared with controls (Fig. $6 a, 38.3 \pm 1.8$ vs $43.8 \pm 1.6 \mathrm{nCi} / \mathrm{gm} ; p<0.05$ ). The most robust decrease in $\mathrm{CRF}_{1}$ mRNA was observed in the basolateral amygdala, in which the expression of this CRF receptor subtype was found to be decreased $32.3 \%$ by chronic alprazolam treatment $(17.2 \pm 1.2$ vs $25.3 \pm 1.8 \mathrm{nCi} / \mathrm{gm} ; p<0.01)$. No significant changes in $\mathrm{CRF}_{1}$ expression were found in the cerebellum, although the $\mathrm{CRF}_{1}$ mRNA signal was decreased by $\sim 10 \%$ in this region.

In contrast to the decreases in expression of the $\mathrm{CRF}_{1}$ receptor, chronic alprazolam treatment led to an increase of $41.6 \%$ in the expression of $\mathrm{CRF}_{2 \mathrm{~A}}$ mRNA within the LS (Fig. $7 a, 17.0 \pm 0.9 \mathrm{vs}$ $12.0 \pm 1.5 \mathrm{nCi} / \mathrm{gm} ; p<0.05)$. There was also a $34.8 \%$ increase in
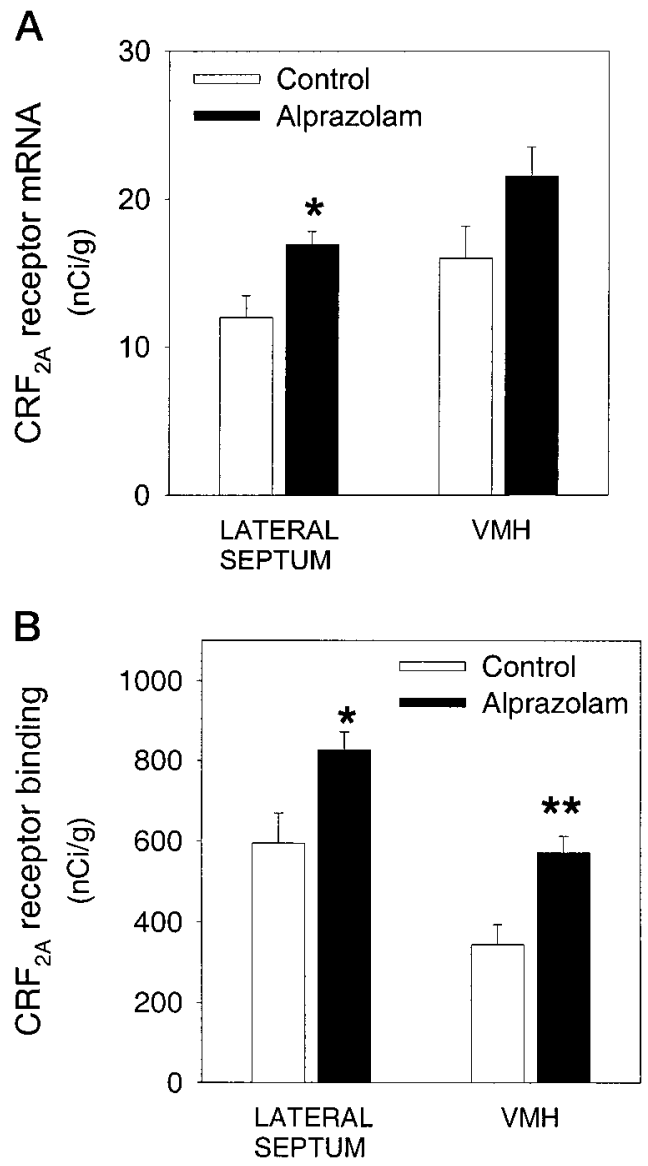

Figure 7. Alterations in $\mathrm{CRF}_{2 \mathrm{~A}}$ receptor function after chronic alprazolam treatment. $a$, Chronic alprazolam increases $\mathrm{CRF}_{2 \mathrm{~A}}$ receptor mRNA in the lateral septum. After $14 \mathrm{~d}$ of incorporation of alprazolam into the diet of male Sprague Dawley rats at a dose of $90 \mathrm{mg} \cdot \mathrm{kg}^{-1} \cdot \mathrm{d}^{-1}, \mathrm{CRF}_{2 \mathrm{~A}}$ receptor mRNA expression was measured via densitometric analysis subsequent to in situ hybridization in the lateral septum and VMH. Each vertical bar represents the mean $\pm \operatorname{SEM}(n=8$ per group). Two to three slices were quantified per region per rat. ${ }^{*} p<0.05$ versus controls after analysis by a two-tailed $t$ test. $b$, Chronic alprazolam increases $\mathrm{CRF}_{2 \mathrm{~A}}$ receptor-binding density in the lateral septum and $\mathrm{VMH}$. After $14 \mathrm{~d}$ of incorporation of alprazolam into the diet of male Sprague Dawley rats at a dose of $90 \mathrm{mg} \cdot \mathrm{kg}^{-1} \cdot \mathrm{d}^{-1}, \mathrm{CRF}_{2 \mathrm{~A}}$ receptor binding was measured by densitometric analysis subsequent to receptor autoradiography performed in the lateral septum and $\mathrm{VMH}$. Total binding was determined using $0.1 \mathrm{nmol} / 1^{125} \mathrm{I}$-sauvagine. $\mathrm{CRF}_{2 \mathrm{~A}}$ binding was determined in the presence of $1 \mu \mathrm{mol} / 1 \mathrm{CP}-154,526\left(\mathrm{CRF}_{1}\right.$-selective antagonist). Nonspecific binding was determined in the presence of $1 \mu \mathrm{mol} / 1$ sauvagine. $\mathrm{CRF}_{2 \mathrm{~A}}$ receptor-specific binding was calculated as $\mathrm{CRF}_{2 \mathrm{~A}}$ binding nonspecific binding. Each vertical bar represents the mean $\pm \operatorname{SEM}(n=8$ per group). Three slices were quantified per region per rat. ${ }^{*} p<0.05$ and $*^{* *} p<0.01$ versus controls after analysis by a two-tailed $t$ test.

the expression of $\mathrm{CRF}_{2 \mathrm{~A}}$ mRNA within the $\mathrm{VMH}(21.6 \pm 2.0 \mathrm{vs}$ $16.0 \pm 2.2 \mathrm{nCi} / \mathrm{gm})$, which did not reach statistical significance.

Alterations in CRF receptor binding demonstrated via autoradiography paralleled the changes in CRF receptor mRNA expression reported above. Chronic alprazolam treatment produced decreases in $\mathrm{CRF}_{1}$ receptor binding, while causing concomitant increases in the density of $\mathrm{CRF}_{2 \mathrm{~A}}$ receptor binding (Figs. 6b, 7b). This effect on $\mathrm{CRF}_{1}$ receptors was most prominent in the BLA. Within this region, $\mathrm{CRF}_{1}$ receptor binding was decreased $45.0 \%$ from that detected in control rats (Fig. $6 b, 1266.2 \pm 116.0$ vs $2301.1 \pm 178.2 \mathrm{nCi} / \mathrm{gm} ; p<0.001)$. As with the mRNA expression, smaller decreases in $\mathrm{CRF}_{1}$ receptor binding were demon- 
strated in the frontal/parietal cortex and cerebellum (16.0 and $30.3 \%$, respectively).

$\mathrm{CRF}_{2 \mathrm{~A}}$ receptor-binding density was markedly increased in both the LS and the VMH (Fig. 7b). Comparable with the increase in its mRNA expression, $\mathrm{CRF}_{2 \mathrm{~A}}$ receptor binding was increased by $39.0 \%$ in the LS $(826.6 \pm 44.9$ vs $594.5 \pm 74.4$ $\mathrm{nCi} / \mathrm{gm} ; p<0.05)$. An even greater enhancement of $\mathrm{CRF}_{2 \mathrm{~A}}$ receptor binding was observed in the $\mathrm{VMH}$. Within this region, binding to $\mathrm{CRF}_{2 \mathrm{~A}}$ receptors was increased by $66.0 \%$ compared with binding in control rats (571.1 \pm 41.2 vs $344.04 \pm 49.3$ $\mathrm{nCi} / \mathrm{gm} ; p<0.01)$.

\section{DISCUSSION}

Pharmacological agents with a high affinity for the benzodiazepine receptor can produce a spectrum of activity from profound sedation to anxiolysis, to anxiogenesis, and even to proconvulsant actions (Owens et al., 1997). These studies confirm and extend our previous reports (Owens et al., 1989, 1991) that acute administration of the benzodiazepine full agonist alprazolam decreases CRF concentrations within the LC and that a partial inverse agonist at the benzodiazepine receptor may cause a reciprocal increase in $\mathrm{CRF}$ concentrations within this region. Although the magnitude of increase is not as great, the effect of the partial inverse agonist FG7142 is similar to that observed after acute or chronic stress (Chappell et al., 1986).

In the areas studied, the chronic administration of alprazolam resulted in a generalized decrease in CRF production, release, and functions mediated via the $\mathrm{CRF}_{1}$ receptor. Specifically, there were reductions in CRF mRNA expression within the CeA, CRF concentrations within the $\mathrm{LC}, \mathrm{CRF}_{1}$ receptor mRNA expression and binding within the BLA, and basal HPA axis activity. In contrast and unexpectedly, our measures of function in the "second" CRF-like system revealed that urocortin mRNA expression within the EWN and $\mathrm{CRF}_{2 \mathrm{~A}}$ receptor function in the LS and $\mathrm{VMH}$ were both increased. This intriguing finding suggests that rather than urocortin and $\mathrm{CRF}_{2 \mathrm{~A}}$ receptors representing a second parallel CRF-like system, perhaps they represent "antiparallel" stress systems. Indeed, opposite effects of $\mathrm{CRF}_{1}$ and $\mathrm{CRF}_{2 \mathrm{~A}}$ receptor systems have been demonstrated recently with respect to learning and memory consolidation in fear conditioning (Radulovic et al., 1999). Until further information is obtained regarding the neurobiology of urocortin and $\mathrm{CRF}_{2 \mathrm{~A}}$ receptors, it is difficult to interpret the findings any further.

One of the primary brain regions where this extensive benzodiazepine-induced modulation of CRF neuronal function occurs is the amygdala, which appears to be an important site for the anxiogenic effects of CRF. A high density of CRF-expressing neurons that communicate widely throughout the brain, particularly to brainstem autonomic nuclei and other limbic structures, is contained within the $\mathrm{CeA}$, and a rich population of CRF receptors composed predominantly of the $\mathrm{CRF}_{1}$ subtype is found within the BLA (Gray and Bingaman, 1996). Studies have demonstrated that stress upregulates the production of CRF mRNA within the CeA (Kalin et al., 1994; Albeck et al., 1997; Hatalski et al., 1998; Hsu et al., 1998) and, furthermore, that basal levels of CRF mRNA expression in rats are increased in both a genetic model of anxiety, as well as in the maternal separation anxiety model based on adverse early-life experience (Altemus et al., 1994-1995; Ladd et al., 2000). Within the amygdala, stress and anxiety are associated with increases in the production and release of CRF, a neuropeptide with demonstrated anxiogenicity in this region, particularly via actions at the $\mathrm{CRF}_{1}$ receptor subtype
(Rassnick et al., 1993; Swiergiel et al., 1993; Liebsch et al., 1995; Pich et al., 1995; Richter and Weiss, 1999). We have found that chronic administration of alprazolam reduces both the expression of CRF mRNA within the CeA, the major output nucleus of the amygdala, and the expression and binding to the $\mathrm{CRF}_{1}$ receptor within the BLA, an amygdaloid nucleus that receives input from widespread regions of the brain. This decrease in the responsiveness of the amygdala to CRF, as well as in the subsequent output of CRF from this important center of fear and anxiety, could be an important/relevant aspect of the mechanism of anxiolytic efficacy of benzodiazepines.

Because the decrease in CRF mRNA within the CeA that we observed was not accompanied by a decrease in local CRF concentrations, it appears likely that these affected CRF-expressing neurons project to targets outside the amygdala. One probable target is the LC. The amygdala is a major source of CRF input to the LC (Koegler-Muly et al., 1993), and recent studies have provided clear evidence that CRF-immunoreactive neurons with cell bodies located in the CeA project to and form synapses on tyrosine hydroxylase-positive LC dendrites in the rostrolateral peri-LC area (Van Bockstaele et al., 1996, 1998). Substantial evidence has accumulated indicating that CRF serves as an excitatory neurotransmitter in the LC (Valentino et al., 1993; Conti and Foote, 1996; Smagin et al., 1997). As in the amygdala, the LC has long been implicated as an essential component of the neural substrates that underlie fear and anxiety (Redmond, 1987; Charney et al., 1995).

Both acute and chronic stress have been shown to produce a twofold increase in LC CRF concentrations (Chappell et al., 1986). Additionally, both CRF concentrations and CRF receptor binding are elevated in two rodent models of adverse early-life experience, which produce persistent increases in anxiety (Caldji et al., 1998; Ladd et al., 2000). As with the amygdala, CRF has been demonstrated to produce behavioral evidence of anxiety when directly injected in the LC (Butler et al., 1990; Weiss et al., 1994). Conversely, stress-induced anxiety and the accompanying norepinephrine release in LC terminal fields are reduced by low doses of CRF antagonists administered directly within the LC (Swiergiel et al., 1992; Smagin et al., 1996, 1997). Taken together, the evidence supports the hypothesis that CRF is endogenously released into the LC in response to certain stressors, perhaps from terminals originating within the $\mathrm{CeA}$, and that it can act within this region as a mediator of anxiety and fear responses. Our results indicate that both acute and chronic treatment with alprazolam decreases CRF concentrations within the LC by $\sim 30 \%$ (Owens et al., 1991). This decrease in CRF stimulatory input to the LC noradrenergic system, plausibly secondary to decreased CRF mRNA expression in neurons of the CeA-LC pathway, may contribute to the anxiolytic effects of benzodiazepines. In view of this, it is particularly interesting to note that both acute and chronic stress produces a similar magnitude of increase in LC CRF content. Likewise, both acute and chronic administration of alprazolam produces similar decreases in LC CRF concentrations (Chappell et al., 1986). Thus, tolerance does not seem to develop to the effects of stress or alprazolam on LC CRF concentrations. If a reduction in LC CRF concentrations is relevant to the anxiolytic action of benzodiazepines, this may be a reason why, unlike other benzodiazepine effects, such as sedation and muscle relaxation, tolerance does not develop to the anxiolytic effects of benzodiazepines.

Like the Caldji et al. (1998) study cited above, which reported parallel increases in CRF concentrations and receptor density in 
the LC, our current results demonstrate that CRF concentrations/ mRNA expression and $\mathrm{CRF}_{1}$ receptor binding/mRNA expression are concurrently decreased by chronic alprazolam administration. Similarly, urocortin mRNA expression and $\mathrm{CRF}_{2 \mathrm{~A}}$ receptor binding/mRNA expression are coordinately upregulated. This runs contrary to the expected inverse relationship between CRF and CRF receptors that is evident within the HPA axis, where CRF receptors in the anterior pituitary are downregulated by CRF or stress (Owens et al., 1991). However, this is not necessarily the case with the extrahypothalamic CRF neuronal systems that are believed to mediate the behavioral and autonomic responses to stress. In separate studies, stress has been shown to upregulate both CRF mRNA expression and/or concentrations and CRF receptor mRNA expression and/or binding in the PVN (Imaki et al., 1996; Kiss et al., 1996), CeA (Fuchs and Flugge, 1995; Pich et al., 1995; Albeck et al., 1997), and LC (Chappell et al., 1986; Caldji et al., 1998). Additionally, CRF, itself, has been shown to upregulate directly the expression of mRNA for its $\mathrm{CRF}_{1}$ receptor subtype (Imaki et al., 1996; Mansi et al., 1996). These parallel changes in ligand availability and receptor density suggest a possibility for positive feedback regulation to increase net neurotransmission through these CRF neuronal circuits. This is teleologically appropriate for a system that evolved to react swiftly and effectively to coordinate an animal's behavioral and autonomic responses to stressors.

One can postulate that after the stressor is no longer present, other mechanisms, such as GABAergic inhibition, may act on the CRF neuronal systems to reset them to baseline activity. We have provided evidence here that potentiating the activity of GABAergic inhibitory neurotransmission with alprazolam causes a coordinate decrease in CRF mRNA expression and $\mathrm{CRF}_{1}$ receptor binding/expression within the amygdala, as well as perhaps in cerebral cortex and cerebellum. The resultant decrease in CRF activity mediated via the $\mathrm{CRF}_{1}$ receptor would be expected to result in diminished expression of anxiety and, therefore, may be a significant mechanism by which benzodiazepines mediate their anxiolytic effects. Most evidence yielded from $\mathrm{CRF}_{1}$ receptor knock-out mice, as well as the administration of $\mathrm{CRF}_{1}$-selective antagonists and antisense, indicates that the $\mathrm{CRF}_{1}$ receptor is the predominant subtype involved in mediating the anxiogenic effects of CRF (Liebsch et al., 1995, 1999; Lundkvist et al., 1996; Heinrichs et al., 1997b; Griebel et al., 1998; Timpl et al., 1998).

Although the effects of a parallel downregulation of CRF and its $\mathrm{CRF}_{1}$ receptor are relatively straightforward to deduce, the effects of the parallel upregulation of $\mathrm{CRF}_{2 \mathrm{~A}}$ receptor binding and mRNA expression for urocortin, the putative endogenous $\mathrm{CRF}_{2 \mathrm{~A}}$ receptor ligand, have less clear neurobiological consequences. Because of the relatively recent discovery of urocortin and the $\mathrm{CRF}_{2 \mathrm{~A}}$ receptor, as well as the lack of selective $\mathrm{CRF}_{2 \mathrm{~A}}$ antagonists, it has been difficult to determine the physiological or behavioral functions mediated or modulated via the $\mathrm{CRF}_{2 \mathrm{~A}}$ receptor. Available data suggest a role of urocortin and the $\mathrm{CRF}_{2 \mathrm{~A}}$ receptor in the central regulation of appetite, food intake, and water balance (Spina et al., 1996; Hara et al., 1997a,b; Martinez et al., 1998; Smagin et al., 1998). However, our current results are not readily attributable to alterations in osmoregulation or nutrient balance.

Some studies have also demonstrated a role for $\mathrm{CRF}_{2 \mathrm{~A}}$ receptors outside of the regulation of food and water balance. Most relevant to our current results is a study in which $\mathrm{CRF}_{2 \mathrm{~A}}$ receptor mRNA expression was found to be decreased in the $\mathrm{VMH}$ by $>60 \%$ after maternal deprivation of rats pups, a manipulation that produces behavioral evidence of heightened anxiety in adulthood. Within the $\mathrm{VMH}$, this decrease in $\mathrm{CRF}_{2 \mathrm{~A}}$ receptor mRNA was returned to control levels, not by selective restoration of food intake, but rather by selective restoration of surrogate grooming and handling (Eghbal-Ahmadi et al., 1997, 1999). The handling of rat pups is a manipulation that has been demonstrated previously to produce less anxious rats in adulthood (Levine, 1957; Denenberg, 1964; Francis et al., 1996). Another recent study reported that although the subchronic inf usion of $\mathrm{CRF}_{2}$ receptor antisense into the lateral ventricle of male rats did not produce an anxiolytic effect as measured in the standard elevated-plus-maze paradigm, it did increase immobility in a forced-swim test. The authors believe that this result demonstrates that $\mathrm{CRF}_{2}$ receptors may selectively influence coping behaviors in response to stress (Liebsch et al., 1999). Thus, although the CRF-CRF receptor $_{1}$ system appears to mediate the expression of anxiety as measured in the classic behavioral paradigms, the urocortin- $\mathrm{CRF}_{2}$ receptor system may play a role in stress-coping behaviors. Therefore, our evidence that alprazolam upregulates binding and expression of the $\mathrm{CRF}_{2 \mathrm{~A}}$ receptor, as well as its putative ligand urocortin, could indicate that an aspect of the efficacy of benzodiazepines in treating anxiety disorders is their ability to increase activity of a neurobiological system involved in coping effectively in stressful or anxiety-provoking situations.

If, as the literature suggests, CRF is involved in the pathogenesis of anxiety disorders, then drugs that effectively treat anxiety may alter the components of CRF neuronal systems that underlie the symptomatolgy of these disorders. Our results support this view. Here we report that the anxiolytic drug alprazolam altered CRF concentrations and mRNA expression, as well as $\mathrm{CRF}_{1}$ and $\mathrm{CRF}_{2 \mathrm{~A}}$ receptor mRNA expression in a manner precisely opposite to lifelong changes observed in rat models of anxiety, based either on genetics (fawn-hooded rat) or on early adverse life experience, whether externally induced by the experimenter (maternal separation) or occurring naturally (low licking-grooming and arched-back nursing). Finally, our results suggest the intriguing possibility that CRF neuronal systems may be composed of two separate, but interrelated, subdivisions $\left(\mathrm{CRF}-\mathrm{CRF}_{1}\right.$ and urocortin- $\mathrm{CRF}_{2}$ ) that can be coordinately and inversely regulated by stress, anxiety models, or anxiolytic drugs.

\section{REFERENCES}

Adinoff B, Anton R, Linnoila M, Guidotti A, Nemeroff CB, Bissette G (1996) Cerebrospinal fluid concentrations of corticotropin-releasing hormone $(\mathrm{CRH})$ and diazepam-binding inhibitor (DBI) during alcohol withdrawal and abstinence. Neuropsychopharmacology 15:288-295.

Albeck D, McKittrick C, Blanchard D, Blanchard R, Nikulina J, McEwen B, Sakai R (1997) Chronic social stress alters levels of corticotropinreleasing factor and arginine vasopressin mRNA in rat brain. J Neurosci 17:4895-4903.

Altemus M, Smith M, Diep V, Aulakh C, Murphy D (1994-1995) Increased mRNA for corticotrophin releasing hormone in the amygdala of fawn-hooded rats: a potential animal model of anxiety. Anxiety 1:251-257.

Baker DG, West SA, Nicholson WE, Ekhator NN, Kasckow JW, Hill KK, Bruce AB, Orth DN, Geracioti Jr TD (1999) Serial CSF corticotropin-releasing hormone levels and adrenocortical activity in combat veterans with posttraumatic stress disorder. Am J Psychiatry 156:585-588.

Bremner J, Licinio J, Darnell A, Krystal JH, Owens MJ, Southwick SM, Nemeroff CB, Charney DS (1997) Elevated CSF corticotropinreleasing factor concentrations in posttraumatic stress disorder. Am J Psychiatry 154:624-629.

Britton K, Morgan J, Rivier J, Vale W, Koob GF (1985) Chlordiazepoxide attenuates CRF-induced response suppression in the conflict test. Psychopharmacology (Berl) 86:170-174. 
Butler PD, Weiss JM, Stout JC, Nemeroff CB (1990) Corticotropinreleasing factor produces fear-enhancing and behavioral activating effects following infusion into the locus coeruleus. J Neurosci 10:176-183.

Caldji C, Tannenbaum B, Sharma S, Francis D, Plotsky P, Meaney M (1998) Maternal care during infancy regulates the development of neural systems mediating the expression of fearfulness in the rat. Proc Natl Acad Sci USA 95:5335-5340.

Chalmers DT, Lovenberg TW, Grigoriadis DE, Behan DP, De Souza EB (1996) Corticotrophin-releasing factor receptors: from molecular biology to drug design. Trends Pharmacol Sci 17:166-172.

Chappell PB, Smith MA, Kilts CD, Bissette G, Ritchie J, Erson C, Nemeroff CB (1986) Alterations in corticotropin-releasing factor-like immunoreactivity in discrete rat brain regions after acute and chronic stress. J Neurosci 6:2908-2914.

Charney DS, Bremner JD, Redmond DE (1995) Noradrenergic neural substrates for anxiety and fear: clinical associations based on preclinical research. In: Psychopharmacology: the fourth generation of progress (Bloom FE, Kupfer DJ, eds), pp 387-395. New York: Raven.

Conti LH, Foote SL (1996) Reciprocal cross-desensitization of locus coeruleus electrophysiological responsivity to corticotropin-releasing factor and stress. Brain Res 722:19-29.

Cowley DS, Roy-Byrne PP, Radant A, Ritchie JC, Greenblatt DJ, Nemeroff CB, Hommer DW (1995) Benzodiazepine sensitivity in panic disorder: effects of chronic alprazolam treatment. Neuropsychopharmacology 12:147-157.

Denenberg VH (1964) Critical periods, stimuli input, and emotional reactivity: a theory of infantile stimulation. Psychol Rev 71:335-351.

De Souza EB, Insel TR, Perrin MH, Rivier J, Vale WW, Kuhar MJ (1985) Corticotropin-releasing factor receptors are widely distributed within the rat central nervous system: an autoradiographic study. J Neurosci 5:3189-3203.

Donaldson CJ, Sutton SW, Perrin MH, Corrigan AZ, Lewis KA, Rivier JE, Vaughan JM, Vale WW (1996) Cloning and characterization of human urocortin. Endocrinology [Erratum (1996) 137:3896] 137: $2167-2170$

Dunn AJ, Berridge CW (1990) Physiological and behavioral responses to corticotropin-releasing factor administration: is CRF a mediator of anxiety or stress responses? Brain Res Rev 15:71-100.

Dunn AJ, File SE (1987) Corticotropin-releasing factor has an anxiogenic action in the social interaction test. Horm Behav 21:193-202.

Eghbal-Ahmadi M, Hatalski CG, Avishai-Eliner S, Baram TZ (1997) Corticotropin releasing factor receptor type II (CRF2) messenger ribonucleic acid levels in the hypothalamic ventromedial nucleus of the infant rat are reduced by maternal deprivation. Endocrinology 138:5048-5051.

Eghbal-Ahmadi M, Avishai-Eliner S, Hatalski C, Baram T (1999) Differential regulation of the expression of corticotropin-releasing factor receptor type $2\left(\mathrm{CRF}_{2}\right)$ in hypothalamus and amygdala of the immature rat by sensory input and food intake. J Neurosci 19:3982-3991.

Francis D, Diorio J, LaPlante P, Weaver S, Seckl JR, Meaney MJ (1996) The role of early environmental events in regulating neuroendocrine development. Moms, pups, stress, and glucocorticoid receptors. Ann NY Acad Sci 794:136-152.

Fuchs E, Flugge G (1995) Modulation of binding sites for corticotropinreleasing hormone by chronic psychosocial stress. Psychoneuroendocrinology 20:33-51.

Gray TS, Bingaman EW (1996) The amygdala: corticotropin-releasing factor, steroids, and stress. Crit Rev Neurobiol 10:155-168.

Griebel G, Perrault G, Sanger D (1998) Characterization of the behavioral profile of the non-peptide CRF receptor antagonist CP-154,526 in anxiety models in rodents. Comparison with diazepam and buspirone. Psychopharmacology (Berl) 138:55-66.

Hara Y, Ueta Y, Isse T, Kabashima N, Shibuya I, Hattori Y, Yamashita $\mathrm{H}$ (1997a) Increase of urocortin-like immunoreactivity in the rat hypothalamo-neurohypophysial system after salt loading and hypophysectomy. Neurosci Lett 227:127-130.

Hara Y, Ueta Y, Isse T, Kabashima N, Shibuya I, Hattori Y, Yamashita H (1997b) Increase of urocortin-like immunoreactivity in the rat supraoptic nucleus after dehydration but not food deprivation. Neurosci Lett 229:65-68.

Hatalski CG, Guiguis C, Baram T (1998) Corticotropin releasing factor mRNA expression in the hypothalamic paraventricular nucleus and the central nucleus of the amygdala is modulated by repeated acute stress in the immature rat. J Neuroendocrinol 10:663-669.
Hawley RJ, Nemeroff CB, Bissette G, Guidotti A, Rawlings R, Linnoila M (1994) Neurochemical correlates of sympathetic activation during severe alcohol withdrawal. Alcohol Clin Exp Res 18:1312-1316.

Heinrichs SC, Pich EM, Miczek K, Britton KT, Koob GF (1992) Corticotropin-releasing factor antagonist reduces emotionality in socially defeated rats via direct neurotropic action. Brain Res 581:190-197.

Heinrichs SC, Min H, Tamraz S, Carmouche M, Boehme SA, Vale WW (1997a) Anti-sexual and anxiogenic behavioral consequences of corticotropin-releasing factor overexpression are centrally mediated. Psychoneuroendocrinology 22:215-224.

Heinrichs SC, Lapsansky J, Lovenberg TW, De Souza EB, Chalmers DT (1997b) Corticotropin-releasing factor $\mathrm{CRF}_{1}$, but not $\mathrm{CRF}_{2}$, receptors mediate anxiogenic-like behavior. Regul Pept 71:15-21.

Hsu DT, Chen FL, Takahashi LK, Kalin NH (1998) Rapid stressinduced elevations in corticotropin-releasing hormone mRNA in rat central amygdala nucleus and hypothalamic paraventricular nucleus: an in situ hybridization analysis. Brain Res 788:305-310.

Imaki T, Nahon JL, Rivier C, Sawchenko PE, Vale W (1991) Differential regulation of corticotropin-releasing factor mRNA in rat brain regions by glucocorticoids and stress. J Neurosci 11:585-599.

Imaki T, Wang XQ, Shibasaki T, Harada S, Chikada N, Takahashi C, Naruse M, Demura H (1995) Chlordiazepoxide attenuates stressinduced activation of neurons, corticotropin-releasing factor (CRF) gene transcription and CRF biosynthesis in the paraventricular nucleus (PVN). Mol Brain Res 32:261-270.

Imaki T, Naruse M, Harada S, Chikada N, Imaki J, Onodera H, Demura H, Vale W (1996) Corticotropin-releasing factor up-regulates its own receptor mRNA in the paraventricular nucleus of the hypothalamus. Brain Res Mol Brain Res 38:166-170.

Kalin NH, Takahashi LK, Chen F-L (1994) Restraint stress increases corticotropin-releasing hormone mRNA content in the amygdala and paraventricular nucleus. Brain Res 656:182-186.

Kalogeras KT, Calogero AE, Kuribayiashi T, Kahn J, Gallucci WT, Kling MA, Chrousos GP, Gold PW (1990) In vitro and in vivo effects of the triazolobenzodiazepine alprazolam on hypothalamic-pituitaryadrenal function: pharmacological and clinical implications. J Clin Endocrinol Metab 70:1462-1471.

Kiss A, Palkovits M, Aguilera G (1996) Neural regulation of corticotropin releasing hormone $(\mathrm{CRH})$ and $\mathrm{CRH}$ receptor mRNA in the hypothalamic paraventricular nucleus in the rat. J Neuroendocrinol 8:103-112.

Koegler-Muly SM, Owens MJ, Ervin GN, Kilts CD, Nemeroff CB (1993) Potential corticotropin-releasing factor pathways in the rat brain as determined by bilateral electrolytic lesions of the central amygdaloid nucleus and paraventricular nucleus of the hypothalamus. J Neuroendocrinol 5:95-98.

Kozicz T, Yanaihara H, Arimura A (1998) Distribution of urocortin-like immunoreactivity in the central nervous system of the rat. J Comp Neurol 391:1-10.

Krahn DD, Gosnell BA, Levine AS, Morley JE (1988) Behavioral effects of corticotropin-releasing factor: localization and characterization of central effects. Brain Res 443:63-69.

Krulik R, Cerny M (1971) Effects of chlordiazepoxide on stress in rats. Life Sci 10:145-151.

Ladd CO, Owens MJ, Nemeroff CB (1996) Persistent changes in corticotropin-releasing factor neuronal systems induced by maternal deprivation. Endocrinology 137:1212-1218.

Ladd CO, Huot RL, Thrivikraman KV, Nemeroff CB, Meaney MJ, Plotsky PM (2000) Long-term behavioral and neuroendocrine adaptations to adverse early experience. In: Progress in brain research: the biological basis for mind body interactions (Mayer E, Saper C, eds), pp 79-101. Amsterdam: Elsevier.

Lee Y, Davis M (1997) Role of the hippocampus, the bed nucleus of the stria terminalis, and the amygdala in the excitatory effect of corticotropin-releasing hormone on the acoustic startle reflex. J Neurosci 17:6434-6446.

Levine S (1957) Infantile experience and resistance to physiological stress. Science 126:405-406.

Liebsch G, Landgraf R, Gerstberger R, Probst JC, Wotjak CT, Engelmann M, Holsboer F, Montkowski A (1995) Chronic infusion of a $\mathrm{CRH}_{1}$ receptor antisense oligodeoxynucleotide into the central nucleus of the amygdala reduced anxiety-related behavior in socially defeated rats. Regul Pept 59:229-239.

Liebsch G, Landgraf R, Engelmann P, Lorscher P, Holsboer F (1999) 
Chronic infusion of CRH1 or CRH2 receptor antisense oligonucleotides into the rat brain differentially affects emotional and stress coping behavior. J Psychiatr Res 33:153-163.

Lundkvist J, Chai Z, Teheranian R, Hasanvan H, Bartfai T, Jenck F, Widmer U, Moreau J-L (1996) A non peptidic corticotropin releasing factor receptor antagonist attenuates fever and inhibits anxiolytic-like activity. Eur J Pharmacol 309:195-200.

Mansi JA, Rivest S, Drolet G (1996) Regulation of corticotropinreleasing factor type 1 (CRF1) receptor messenger ribonucleic acid in the paraventricular nucleus of rat hypothalamus by exogenous CRF. Endocrinology 137:4619-4629.

Martinez V, Barquist E, Rivier J, Tache Y (1998) Central CRF inhibits gastric emptying of a nutrient solid meal in rats: the role of the $\mathrm{CRF}_{2}$ receptors. Am J Physiol 274:G695-G700.

Owens MJ, Nemeroff CB (1991) Physiology and pharmacology of corticotropin-releasing factor. Pharmacol Rev 43:425-473.

Owens MJ, Bissette G, Nemeroff CB (1989) Acute effects of alprazolam and adinazolam on the concentrations of corticotropin-releasing factor in the rat brain. Synapse 4:196-202.

Owens MJ, Vargas MA, Knight DL, Nemeroff CB (1991) The effects of alprazolam on corticotropin-releasing factor neurons in the rat brain: acute time course, chronic treatment and abrupt withdrawal. J Pharmacol Exp Ther 258:349-356.

Owens MJ, Mulchahey JJ, Stout SC, Plotsky PM (1997) Molecular and neurobiological mechanisms in the treatment of psychiatric disorders. In: Psychiatry (Tasman A, Kay J, Lieberman JA, eds), pp 210-257. Philadelphia: Saunders.

Paxinos G, Watson C (1986) The rat brain in stereotaxic coordinates. San Diego: Harcourt Brace Jovanovich.

Pich EM, Lorang M, Yeganeh M, Rodriguez de Fonseca F, Raber J, Koob GF, Weiss F (1995) Increase of extracellular corticotropinreleasing factor-like immunoreactivity levels in the amygdala of awake rats during restraint stress and ethanol withdrawal as measured by microdialysis. J Neurosci 15:5439-5447.

Primus RJ, Yevich E, Baltazar C, Gallager DW (1997) Autoradiographic localization of CRF1 and CRF2 binding sites in adult rat brain. Neuropsychopharmacology 17:308-316.

Radulovic J, Ruhmann A, Liepold T, Spiess J (1999) Modulation of learning and anxiety by corticotropin-releasing factor (CRF) and stress: differential roles of CRF receptors 1 and 2. J Neurosci 19:5016-5025.

Rassnick S, Heinrichs SC, Britton KT, Koob GF (1993) Microinjection of a corticotropin-releasing factor antagonist into the central nucleus of the amygdala reverses anxiogenic-like effects of ethanol withdrawal. Brain Res 605:25-32.

Redmond DE (1987) Studies of the nucleus locus coeruleus in monkeys and hypotheses for neuropsychopharmacology. In: Psychopharmacology: the third generation of progress (HY Meltzer, ed), pp 967-976. New York: Raven.

Richter RM, Weiss F (1999) In vivo CRF release in rat amygdala is increased during cocaine withdrawal in self-administering rats. Synapse $32: 254-261$.

Rohrer T, Von Richthofen V, Schulz C, Beyer J, Lehnert H (1994) The stress-, but not corticotropin-releasing hormone-induced activation of the pituitary-adrenal axis in man is blocked by alprazolam. Horm Metab Res 26:200-206.

Sanchez MM, Young LJ, Plotsky PM, Insel TR (1999) Autoradiographic and in situ hybridization localization of corticotropin-releasing factor 1 and 2 receptors in nonhuman primate brain. J Comp Neurol 408:365-377.

Simmons DM, Arriza JL, Swanson LW (1989) A complete protocol for in situ hybridization of messenger RNAs in brain and other tissues with radiolabeled single-stranded RNA probes. J Histotechnol 12:169-181.
Skutella T, Criswell H, Moy S, Probst JC, Breese GR, Jirikowski GF, Holsboer F (1994) Corticotropin releasing hormone (CRH) antisense oligodeoxynucleotide induces anxiolytic effects in rat. NeuroReport 5:2181-2185.

Smagin G, Howell L, Ryan D, DeSouza E, Harris R (1998) The role of $\mathrm{CRH}_{2}$ receptors in corticotropin-releasing factor- and urocortininduced anorexia. NeuroReport 9:1601-1606.

Smagin GN, Harris RB, Ryan DH (1996) Corticotropin-releasing factor receptor antagonist infused into the locus coeruleus attenuates immobilization stress-induced defensive withdrawal in rats. Neurosci Lett 220:167-170.

Smagin GN, Zhou J, Harris RB, Ryan DH (1997) CRF receptor antagonist attenuates immobilization stress-induced norepinephrine release in the prefrontal cortex in rats. Brain Res Bull 42:431-434.

Spina M, Merlo-Pich E, Chan RKW, Basso AM, Rivier J, Vale W, Koob GF (1996) Appetite-suppressing effects of urocortin, a CRF-related neuropeptide. Science 273:1561-1564.

Swanson LW, Sawchenko PE, Rivier J, Vale WW (1983) Organization of ovine corticotropin-releasing factor immunoreactive cells and fibers in the rat brain: an immunohistochemical study. Neuroendocrinology 36:165-186.

Swerdlow NR, Geyer MA, Vale WW, Koob GF (1986) Corticotropin releasing factor potentiates acoustic startle in rats: blockade by chlordiazepoxide. Psychopharmacology (Berl) 88:147-152.

Swiergiel AH, Takahashi LK, Rubin WW, Kalin NH (1992) Antagonism of corticotropin-releasing factor receptors in the locus coeruleus attenuates shock-induced freezing in rats. Brain Res 587:263-268.

Swiergiel AH, Takahashi LK, Kalin NH (1993) Attenuation of stressinduced behavior by antagonism of corticotropin-releasing factor receptors in the central amygdala in the rat. Brain Res 623:229-234.

Timpl P, Spanagel R, Sillaber I, Kresse A, Reul J, Stalla G, Blanquet V, Steckler T, Holsboer F, Wurst W (1998) Impaired stress response and reduced anxiety in mice lacking a functional corticotropin-releasing hormone receptor. Nat Genet 19:162-166.

Valentino RJ, Foote SL, Page ME (1993) The locus coeruleus as a site for integrating corticotropin-releasing factor and noradrenergic mediation of stress responses. Ann NY Acad Sci 697:173-188.

Van Bockstaele EJ, Colago EE, Valentino RJ (1996) Corticotropinreleasing factor-containing axon terminals synapse onto catecholamine dendrites and may presynaptically modulate other afferents in the rostral pole of the nucleus locus coeruleus in the rat brain. J Comp Neurol 364:523-534.

Van Bockstaele EJ, Colago EE, Valentino RJ (1998) Amygdaloid corticotropin-releasing factor targets locus coeruleus dendrites: substrate for the co-ordination of emotional and cognitive limbs of the stress response. J Neuroendocrinol 10:743-757.

Vaughan J, Donaldson C, Bittencourt J, Perrin MH, Lewis K, Sutton S, Chan R, Turnbull AV, Lovejoy D, Rivier C, Rivier J, Sawchenko PE, Vale W (1995) Urocortin, a mammalian neuropeptide related to fish urotensin I and to corticotropin-releasing factor. Nature 378:287-292.

Weiss JM, Stout JC, Aaron MF, Quan N, Owens MJ, Butler PD, Nemeroff CB (1994) Depression and anxiety: role of the locus coeruleus and corticotropin-releasing factor. Brain Res Bull 35:561-572.

Wong M-L, Al-Shekkhlee A, Bongiorno PB, Esposito A, Khatri P, Sternberg EM, Gold PW, Licinio J (1996) Localization of urocortin messenger RNA in rat brain and pituitary. Mol Psychiatry 1:307-312.

Zhao L, Donaldson C, Smith G, Vale W (1998) The structures of the mouse and human urocortin genes (Ucn and UCN). Genomics $50: 28-38$. 